\title{
Creating Built Environments: Bridging Knowledge and Practice Divides
}

\author{
Roderick J. Lawrence \\ New York, United States of America: Routledge, 266 pp., 2020 \\ ISBN: 978-0-8153-8538-7 (hbk); 978-0-8153-8539-4 (pbk); 978-1-351-20167-4 (eBook)
}

Reviewed by Andrew MacKenzie ${ }^{1}$

Recommended citation (APA 7th ed.)

MacKenzie, A. (2021). Review: Creating built environments: Bridging knowledge and practice divides by Roderick J. Lawrence. Human Ecology Review, 27(1), 165-169. doi.org/ 10.22459/HER.27.01.2021.09

Creating Built Environments: Bridging Knowledge and Practice Divides asks the reader to consider the two notions set out in the following statement that encapsulates Roderick Lawrence's principal motivation for writing this book: "The urban condition embodies a cultural crisis that should concern policy makers, property investors, researchers and professionals in the field of land-use planning and built environments" (p. 4). The first notion argues that the cities and towns we live in reflect, more than they determine, the underlying problems facing society today. The second is that the problems, and by definition the pathways to solutions, can and should primarily be addressed by land use planning and built-environment professions. On being presented with such a discussion, I was looking forward to a solid analysis of the following questions emerging from this statement: What is the cultural crisis that the urban condition embodies? And what is the concern that should focus the minds of built-environment decision-makers and practitioners? Creating Built Environments seeks to provide methods for addressing the second question by staking out the parameters for action by resolving the first.

Lawrence has given some thought to the cultural crisis occupying the minds of professionals who may be interested in this book. According to Lawrence, the twentyfirst century city is a product of decisions and actions over centuries that has stripped culture from place, resulting in the production of dehumanizing environments that are devoid of meaning. Placelessness is the term used by Lawrence to capture the essential cultural crisis. Derived from the term "non-place," "placelessness" is a neologism coined by Marc Augé (1992/1995), who argues that the perception of place is entirely subjective and therefore different spaces have different meanings

1 The Fenner School of Environment and Society, The Australian National University, Canberra, Australia: andrew.mackenzie@anu.edu.au. 
to people depending on their relationship to that space. Lawrence adopts a more dogmatic response, suggesting that nature affords fundamental values and meanings to urban spaces, and that its demise results in a diminished experience of urban life. A discussion on the variegations of place theory is not the aim of this book; instead the conception of the cultural crisis in these terms serves as a vehicle to construct the central argument. Lawrence is unequivocal that diminishing humannature relationships, reflected in the contemporary urban condition, are enemy number one; a concern that many of us in the built-environment professions have bought into.

Lawrence buttresses his approach for changing the way we should develop our cities with two arguments. The first is that cultural knowledge is essential to make sense of the threat that climate change represents and where technology cannot mitigate. The second is to reconceptualize the place of nature in the urban policy and decisionmaking process. In presenting such a broad-ranging and comprehensive thesis, it is important to understand Lawrence's argument in relation to complementary theories. For example, Lawrence makes the distinction between "green" and "natural"in other words, the difference between urban greening and urban nature. As a landscape architect, this is refreshing, especially from an author who is an expert on the built aspects of the city. Nature is deployed defensively by Lawrence as a bulwark to the many vagaries of the "greening" doctrine (green technology, green politics, and green infrastructure). In essence, the first part of Creating Built Environments: Bridging Knowledge and Practice Divides is a cautionary tale to decision-makers to not obfuscate nature as a subset of an ecological modernization/green technology policy agenda.

In doing so, Lawrence presents the reader with a novel and refreshing way to read the city. He asks us to reconceptualize urban policy through the lens of humannature relations. He asks the reader to think about systems-based, cross-disciplinary, and cross-cultural understandings of the urban condition, and yet, in Lawrence's mind, the place of nature is unequivocal, unambiguous, and reassuring. The author cites Ann Whiston Spirn (1984) to reinforce this point that "nature has been seen as a superficial embellishment; as a luxury, rather than an essential force which permeates the city" (p. 35). Whereas Spirn was objecting to the superficial treatment of nature primarily by landscape architecture, Lawrence updates Spirn's argument to reposition nature as a policy tool that is as potent as green technology in addressing climate change challenges. Despite these clear boundaries between nature and green technology, the author is not advocating against green innovation. Instead Lawrence seeks to tease out methodological approaches by exploring the city as a complex knowledge domain — essentially reinforcing the author's desire to focus the reader's attention on understanding and enhancing human-nature interactions rather than retreating to discipline- and technology-specific solutions. 
In the tradition of Alexander (1977), Lawrence offers a response to this cultural crisis by asking the reader to join his intellectual journey, founded on the principles of human ecology, of deconstructing a range of urban systems through the lens of human-nature relations. In doing so, the author joins a long tradition of scholars reclaiming the role of nature in cities but goes further, to argue that the endgame for built-environment professionals is to maximize this endeavor as a means to an end. Lawrence invites the reader to bridge epistemological and disciplinary divides, including the divides between people and built environments, and between people and nature. Again, stepping though this discussion we can trace the thinking on urban scholarship going back to Howard, Geddes, Mumford, Jacobs, and McHarg; therefore grounding his theoretical development within an established twentiethcentury urban canon.

Lawrence's contribution to this discussion is to propose a refocused effort to interrogate the human-nature dialog through the lens of five domains, each to a varying degree drawing on the value of nature in enhancing the urban condition. Constructing with nature in mind is the first domain. It essentially unpacks the importance of human-nature relations and how it can be applied in a land use planning framework by drawing on the tradition of city parks, green belts, and reserves to serve as a counterbalance to contemporary urbanizing forces. He touches on the commodification of nature. It is inevitable that landscape value and land uses are commodified, and yet the case study of Singapore demonstrates how cogent policies can potentially translate the commodification of nature to a city's benefit, albeit in a stylistic manner.

Domain two, planning for health and well-being, and domain three, food for thought, apply to urban policy the value of nature for human health benefits. However, Lawrence does point out the difficulty of empirically defending the role of urban nature in evaluating health policy. For example, ecological models have been strongly criticized by epidemiologists. Acknowledging the shortcomings of valuing nature, Lawrence presents a range of conceptual models for determining health outcomes. Increasingly, urban scholars are also interested in the role of food production and consumption in the built environment- $\mathrm{a}$ topic that covers a broad range of issues linked to health, climate change mitigation, inequality, and justice. Food, like housing, is deployed here as a metaphor to argue for a more synergistic approach to addressing the urban condition. Food sovereignty is, for Lawrence, a discussion about systems, processes, and scales of interaction. Case studies of Todmorden (United Kingdom) and Detroit (United States) go to show that food production reveals how exposed urban residents are to a range of modern urban ills, and how food production can serve to enhance mental and physical health outcomes. When physical health indicators decline, often triggered by deindustrialization and population decline, food sovereignty can become a metaphor for social solidarity and improved well-being, at least in a limited sense. 
Domain four, housing matters for all, digresses from the central thesis of humannature relations, but touches on issues of social justice primarily because housing is an essential social, economic, and structural component of the built environment. Housing offers a way into exploring the issues of governance, public finance, and equity. Lawrence points to the problem of delegation of decision-making to communities without adequate funding (e.g., semi-formal residents' associations that emerge in protest to poor government support and regulatory oversight) and how this can lead to confrontation instead of cooperation. This is an important point to make, but difficult to contextualize within the fundamental questions the book is seeking to unravel.

Domain five, creating adaptations and co-producing transformations, draws on a number of epistemological foundations revealing the author's own intellectual journey to traverse a range of knowledge domains. It covers a range of complex overlapping mental models that do not reside in any one disciplinary tradition. Creating Built Environments serves as a compendium of the author's evolution in his research throughout his career. It is interesting to see how Lawrence constructs his own epistemological foundations for his own practice, and it is revealing the extent to which he details his thought process.

The last section of the book offers methodological prescriptions, (e.g., polycentric governance) for moving past sticky urban problems, especially when governments and leaders are unwilling or unable to take the initiative in response to groundswell community activism. More than once, Lawrence pushes the reader off-keel in the chapter "Fundamental values," directing the reader to briefly digress from his previous commitment to broad understandings to a more narrow dogmatic response. He does this to argue the point that human-nature relations should frame decision-making. Lawrence uses case studies to demonstrate how the constraints of professional practice can be overcome in the endeavor to re-center nature in the decision spaces in professional practice.

Lawrence brings us full circle to reflect on his own thinking journey as an academic and explains how, in large part, human ecology has provided a point of orientation to the myriad of questions and problems he sees in the methodological approaches to urban policy development. I found myself going back to earlier chapters to make sense of the connections and, in doing so, felt that a more complete summary of Lawrence's own intellectual framing at the beginning of the book would have helped me in those "aha" moments.

In weaving his own theoretical development into the concluding chapters of the book, Lawrence muses on a policy-practice paradox that is revealed though this analysis. In the end, he presents a novel approach to problem identification, locating 
the professional in the complex system, ethical considerations, and scoping personal limitations, despite the political agendas that interplay in the networked nature of systems (his critique of urban "tinkering" is an example).

Lawrence leaves the reader with a compendium of approaches situated within a cogent argument for inserting more explicit human-nature interactions into cities, and applies his conceptual thinking in practice-or at least, pathways for policy makers to navigate their own approach to thinking about and applying humannature relationships at the forefront of urban policy.

\section{References}

Alexander, C. (1977). A pattern language: Towns, buildings, construction. Oxford University Press.

Augé, M. (1995). Non-places: An introduction to anthropology of supermodernity (J. Howe, Trans.). Verso. (Original work published 1992).

Spirn, A. W. (1984). The granite garden: Urban nature and human design. Basic Books. 
This text is taken from Human Ecology Review, Volume 27, Number 1, 2021, published by ANU Press, The Australian National University, Canberra, Australia.

doi.org/10.22459/HER.27.01.2021.09 